\title{
The Quality of Work life and Job Satisfaction of Private Sector Employees
}

\author{
Laveena D’Mello ${ }^{1}$, Meena Monteiro ${ }^{2}$ and Nelson Pinto ${ }^{3}$ \\ ${ }^{1}$ Assistant Professor, College of Social Work, Srinivas University, Mangalore, Karnataka, India \\ ${ }^{2}$ Associate Professor, MSW Department, School of Social Work, Roshni Nilaya, Mangalore, \\ Karnataka, India \\ ${ }^{3}$ Research scholar, Department of Sociology, Mangalore University, Karnataka, India. \\ E-mail: lavynoronha@gmail.com
}

Type of the Paper: Research Paper.

Type of Review: Peer Reviewed.

Indexed in: OpenAIRE.

DOI: http://doi.org/10.5281/zenodo.1156175.

Google Scholar Citation: $\underline{\text { IJMTS }}$

\section{How to Cite this Paper:}

D’Mello, Laveena., Monteiro, Meena., \& Pinto, Nelson. (2018). The Quality of Work life and Job Satisfaction of Private Sector Employees. International Journal of Management, Technology, and Social Sciences (IJMTS), 3(1), 11-17.

DOI: http://doi.org/10.5281/zenodo.1156175.

International Journal of Management, Technology, and Social Sciences (IJMTS)

A Refereed International Journal of Srinivas University, India.

(C) With Authors.

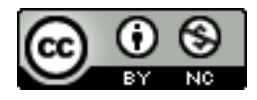

This work is licensed under a Creative Commons Attribution-Non Commercial 4.0 International License subject to proper citation to the publication source of the work.

Disclaimer: The scholarly papers as reviewed and published by the Srinivas Publications (S.P.), India are the views and opinions of their respective authors and are not the views or opinions of the SP. The SP disclaims of any harm or loss caused due to the published content to any party. 


\title{
The Quality of Work life and Job Satisfaction of Private Sector Employees
}

\author{
Laveena D’Mello ${ }^{1}$, Meena Monteiro ${ }^{2}$ and Nelson Pinto ${ }^{3}$ \\ ${ }^{1}$ Assistant Professor, College of Social Work, Srinivas University, Mangalore, Karnataka, India \\ ${ }^{2}$ Associate Professor, MSW Department, School of Social Work, Roshni Nilaya, Mangalore, \\ Karnataka, India \\ ${ }^{3}$ Research scholar, Department of Sociology, Mangalore University, Karnataka, India. \\ E-mail: lavynoronha@gmail.com
}

\begin{abstract}
Earlier people had sincerity and commitment in the work they do. But today an employee would not believe in such values of work. He works very hard to get a handsome salary to sustain his living. Along with this the most interesting motivation is the quality of working life which is a systematic approach to design and a promising development in the broad area of job enrichment. The criteria for measuring the quality of work life are Adequate and fair compensations, healthy working conditions, Opportunity to use and develop human capacities, Opportunity for career growth, Social Integration in the workforce, Work and quality of life, the Social relevance of work etc. The study shows that when there is better quality at work the productivity of the employees' increases. Thus the quality of work life can lead to organizational effectiveness; organizational commitment, job satisfaction, providing employee motivation; personal growth and development enhance competencies which in turn would lead to increase productivity and profit. It also becomes important that suitable working condition will definitely influence the quality of work. The main aim of this research is to study the quality of work life of the private sector employees. Interview scheduled and the objectives are to study the various issues of the private sector employers and job satisfaction. 50 private service employees were selected randomly for the research to ask their opinion and the issues. Both primary and secondary source of information is used in the study.
\end{abstract}

Keywords: Work life, Performance, Employee, Occupational stress, Job enrichment.

\section{INTRODUCTION :}

Employees at the grass-root level experiences a sense of frustration because of low level wages, poor working conditions, unfavourable terms of employment, inhuman treatment by their superiors and the like whereas managerial personnel feel frustrated because of alienation over their conditions of employment, interpersonal conflicts, role conflicts, job pressures, lack of freedom in work, the absence of challenging work etc.[1-3] Certain values were attributed to work in the past. Quality of work life can mean difficult things to different people but in recent years it has come to stand for a participative philosophy of work and organization-a people and bottom line philosophy. The quality of work life organizational philosophy centres on the dignity of respect accorded employees, the nature of their involvement in their work and the goal of excellence for their organizations. The quality of work life is employees at the levels in an organization to use their knowledge, Skills, and abilities more efficiency in their work at their new workplace. Quality of work life is not only a very broad approach to job enrichment but also an interdisciplinary field of inquiry and action combining industrial and organizational psychology and sociology, industrial 
engineering, organizational theory and development motivation and leadership theory and industrial relations. Quality of work life has received enthusiastic support from a number of sources [4-7].

\section{AIM OF QUALITY OF WORK LIFE (QWL) :}

The quality of work life (QWL) is a large step forward from the traditional job designs of scientific management, which focused mostly on specialization and efficiency for the performance of narrow tasks. As it evolved it used full division of labor, raged hierarchy and standardization of labor to rich its objective of efficiency. The idea was to lower costs by using unskilled, respective labor that could be trained easily to do a small part of the job. A large hierarchy that strictly enforced the one best way of work as defined technical people controlled job performance. The result was higher turnover and absenteeism, quality declined and workers became alienated, conflict arose as workers tired to improve their conditions. Some of the criteria for measuring the quality of work life (QWL) are; Adequate and fair compensations: These are different opinions about adequate compensation. The committee on fair wages defined fair wage as the wage which is above the minimum wage but below the living wage. Safe and healthy working conditions: Most of the organizations provide safe and healthy working conditions due to humanitarian requirements. Opportunity to use and develop human capacities: contrary to the traditional assumptions the quality of work life (QWL) is improved to the extent that the worker can exercise more control over his or her work. Opportunity for career growth: Opportunities for promotion are limited in case of all categories of employees either due to educational barriers or due to limited openings at the higher level. The quality of work life (QWL) provides future opportunity for continued growth and security by expanding one's capabilities, knowledge and qualifications. Social Integration in the workforce: Social integration in the workforce can be established by creating freedom from prejudice, supporting primary work groups, a sense of community and interpersonal openness and improvement. Work and quality of life: The quality of work life (QWL) provides for the balanced relationship among work, non-work and family aspects of life. In other words family life and social life should not be strained by working hours including overtime work, work during inconvenient hours, business travel, transfers, vacations, etc. Social relevance of work: The quality of work life (QWL) is concerned about the establishment of social relevance to work in a socially beneficial manner [8-9].

\section{SPECIFIC ISSUES IN QUALITY OF WORK LIFE (QWL) :}

Pay and stability of employment: Good pay still dominates most of the other factors in employee satisfaction. Various attractive means for providing wages should be developed in view of the increase in the cost of living index, enhancing the facilities for human resource management can provide stability to a greater extent.

Occupational stress: Stress is a condition of strain on one's emotions, thought the process and physical conditions, stress is determined by the nature of work. Working conditions, working hours, pause in the work schedule, worker's abilities and nature and match the job requirements.

Organizational health programs: Organizational health programs aims at educating employee about health problems, means of maintaining and improving health etc. Effective implementation of these programs results in the reduction in absenteeism, hospitalization, disability, excessive job turnover and premature death [10-12].

Recognition: Recognizing the employee as a human being rather than as a labourer increases QWL participative management, awarding the rewarding systems, congratulating the employee for their achievement, job enrichment, offering prestigious designation and providing well furnished and decent workplaces, offering membership in clubs or association, providing vehicles offering vacation trips are some means to recognize the employs. Congenial workersupervisor relations: A harmonious supervisor- 
worker relation gives the worker a sense of social association, belongingness, achievement of work results etc. Seniority and merit in promotions: Seniority is generally taken as the basis for promotion in case of operating employees. Merit is considered as the basis for advancement for managerial people whereas seniority cum-merit is preferred for the promotion of ministerial employees. After contributing to the problem was that the workers themselves were changing.

Promotion: A promotion takes place when an employee moves to a position higher than the one formerly occupied. The promotion without increment is called 'dry' promotion. A dry promotion is usually made decorative by giving a new and longer title to the employee which will not have any effect on employee promotions. If promotion gives an opportunity to the employees to move into jobs that provide greater personal satisfaction and prestige, should also include some incentives which will motivate him to perform better [13-14].

\section{CAREER PLANNING :}

If an organization wants to retain its employees it must satisfy their innate aspirations for growth and development, of advancement in their career. A career plan is a blueprint in which the entire career of employees is mapped out from the point of their entry into the point of their retirement from the organization. From this blueprint, the employee knows about the career paths they can follow and the training and development facilities, which are available to them for preparing higher responsibilities. Career planning is mostly done only for supervisory and managerial positions and not for all the employees of an organization. Hence it is sometimes described as the planning for 'blueeyed' jobs. Career planning is an integral part of manpower planning's without it we cannot get a picture of that individual in the organization that holds promise for development and therefore be groomed for higher-level assignments in future [15].

Advantages of career planning: It motivates employees to avail of the training and development facilities. They are convinced that promotions will not fall into their laps merely by luck or through connections. It increases employee's loyalty to the organization because they are convinced about the organization's care for them and can easily integrate their goals with organizational goals. It encourages employees to remain in the organization. As a result lab our turnover is reduced and with it the cost of hiring people. It creates organizations better image in the employment market, which helps the organization to attract competent people. It contributes to manpower planning as well as to organizational development and effective achievement of the corporate goal [16-17].

\section{FINDINGS :}

Personal information of the employers:

Age: 18 percent of the respondents are below 30 years of age, 26 percent are between the age of 31-40, and rest 56 percent of the respondents are above 41 years. So the majority of the respondents are above 41 years.

Gender: 64 percent of the respondents are female and 36 percent are male.

Educational qualification of the respondents: 52 percent of the respondents will have PUC and technical qualification, 26 percent will have graduation and 22 percent of the employers are postgraduates.

Work experience: 18 percent of the respondents have below 5 years of work experience, 42 percent respondents have 5-10 years experience and rest 40 percent of the respondents will have more than 10 years of experience.

Area: 84 percent of the respondents are from the urban area and only 16 percent are from the rural area, it shows majority will have more opportunities to get private employment in cities.

Working condition:

Field of working: private service respondents are taken from five main fields equally. 20 percent each from NGO sector, technical sector, private companies like clerical and office assistance, private banks and schools.

Working condition: 54 percent of the respondents shared they working condition is excellent and 46 Percent are satisfactory with the working condition. 46 percent of the employees 
are happy with the pay scale they get, 30 percent are just satisfied and remaining 24 percent are not satisfied with the pay scale they receive. Career growth opportunities: 44 percent of the respondents feel that they have career growth opportunities, 26 percent of the respondents are not happy and they do not have an opportunity for their career growth and remaining 30 percent are not sure about their job and continuity.

Job satisfaction: Job satisfaction can also be seen within the broader context of the range of issues which affect an individual's experience of work, or their quality of working life. Job satisfaction can be understood in terms of its relationships with other key factors, such as general wellbeing, stress. 44 percent of the respondents feel that they are highly satisfied with the current job, 40 percent of respondents are moderately satisfied with their job than 6 percent of respondents are dissatisfied with the current job. Recognition of an employee will give them job satisfaction and also build up their selfesteem.74 percent of the respondents are recognized by their employers and they feel they have status but remaining 26 percent feel that they are not considered or there is no recognition for their work and service at the private sector. Facilities are given to the employees at the workplace and those facilities are modified as and when the situation and the desire of the employers. 30 percent of the respondents are given facilities, benefits, leave but remaining 70 percent are not satisfied with the benefits and facilities are given by the private sectors. Payment and salary is a concern, most of the respondents 42 percent are satisfied with the salary remaining majority 58 percent are not satisfied with the pay scale and the mode of salary payment. Most of the time it was uncertain and delay and payment in instalments. But they have with the opinion that they can take advance for the emergency situations. All these components directly or indirectly have an effect on quality of work life.

\section{CONCLUSION :}

The term quality of work life is well-accepted fact, that an employee spends one-third of their life in the workplace. Whatever they do at their workplace, they carry it back to their home and the situation prevailing at their home affects their performance at work. The study shows that when there is better quality at work the productivity of the employees' increases. Thus we can conclude that by increasing the quality of work life, it can further lead to organizational effectiveness, organizational commitment, job satisfaction, providing employee motivation, which in turn would lead to increased productivity and profit. It also becomes important that suitable working condition will definitely influence the quality of work [18-19].

\section{SUGGESTIONS}

Based on the study, the suggestions are; the overall working facilities can be improved so that the employees should feel comfortable at work. There should be a platform for the employees to express their grievance through suggestion box, collecting the employee feedback so that organization can improve its performance level and as well as employee quality of work. Periodical training on skill development and quality of work is required. A better reward system can be introduced for those who maintain quality at work. Promotion, salary, and increments should be given to the employees based on experience, hard work, and performance [20-24].

\section{REFERENCES :}

[1] D’Mello Laveena, H. H. Manjush, Monteiro Meena (2016). A Study on the Green Human Resource Management at Gateway Hotel, Mangalore. International Journal of Scientific Research and Modern Education (IJSRME) 1(1), 843-852.

[2] Sonia Delrose Noronha \& P. S. Aithal (2016). Glass Ceiling- A Silent Barrier for Women in Highly Advanced and Humanistic Society. International Journal of Management \& Social Sciences ISSN 24552267, 5(3). DOI: http://dx.doi.org/10. 21013/jmss.v5.n3.p9.

[3] Sonia Delrose Noronha \& P. S. Aithal (2017). Organizational Strategic Approach towards Work Life Balance of Women in India. International Journal of Management, 
Technology, and Social Sciences(IJMTS), 2(1),18-24, DOI: http://dx.doi.org/10.52 81/zenodo.810349.

[4] Sonia Delrose Noronha, Aithal, P. S.\& Pradeep, M.D. (2017). Study on the Policy Framework Towards Work Life Balance in India. International Journal of Multidisciplinary Research and Modern Education (IJMRME), 3(2), 11-16.DOI : http://doi.org/10.5281/zenodo.839258.

[5] D’Mello Laveena, \&Monterio Meena (2017). A Study on Causes and Effects of Migration from Rural to Urban: A Case Study of Bijapur Colony- Ligapayyankakadu, Mulki International Journal of Case Studies in Business, IT and Education (IJCSBE), 1 (2), 37-43, DOI: http://dx.doi.org/10.5281/zenodo. 1004672.

[6] Lawler E. E. (1982). Strategies for improving the quality of work life. American Psychologist, 37, 2005, 486-493.

[7] Shamir B. and Salomon, I. (1985). Work-athome and the quality of working life. Acad. Manag., 10, 455-64.

[8] Straw R.J. and Heckscher, C. C. (1984). QWL: New working relationships in the communication industry. Labor Studies J., 9, 261-74.

[9] Herman Aguinis (2008). Performance Management. Pearson Education Publication, US.

[10] Mamoria C.B. and Sathish Mamoria (1998). Dynamics of Industrial Relations. Himalaya Publishing House, New Delhi.

[11] Dwivedi. R.S. (1997). Human Relations \& Organizational Behavior. Macmillan India Ltd., New Delhi.

[12] Monterio Meena, D’Mello Laveena,\& Govindaraju, B. M. (2017). A Study on the Working Conditions of Sales Persons in a Garment Shop at Mangalore. International Journal of Case Studies in Business, IT and Education (IJCSBE), 1 (1), 67-71, DOI: http://dx.doi.org/10.5281/zen odo.584118.
[13] Ratna Sen (2003). Industrial Relations in India', Shifting Paradigms. Macmillan India Ltd., New Delhi.

[14] Gareth R.Jones (2004). Organizational Theory, Design \&Change. Pearson Education, US.

[15] Robbins (2005). Organization Theory; structure design \&Application. Prentice hall of India, India.

[16] Richard L. Daft (2007). Understanding the theory \& design of organizations. Thomson south western.

[17] Greenhaus J.H., Parasuraman, S. \& Wormley W.M. (1990). Effects of race on organizational experience, job performance evaluations, and career outcomes. Academy of Management Journal, 16, 129-137.

[18] Subba Rao, P. (2013). Essential of human resource management and industrial relation. Himaya publishing house, $5^{\text {th }}$ Edition, Bangalore, India.

[19] Subba Rao, P. (2009). Personnel management and human resource management. Himaya publishing house, Bangalore, India.

[20] Aithal, P. S. \& Suresh Kumar P. M. (2017). Interconnecting Theory A and ABC Model of Organizational Performance. International Journal of Management, Technology and Social Sciences (IJMTS), 1(1), 1-13. DOI: http://dx.doi.org/10.5281/ze nodo.268598.

[21] Aithal, P. S., \& Suresh Kumar P. M. (2017). Integrating Theory A and Six Thinking Hats for Improved Organizational Performance. International Journal of Applied Engineering and Management Letters (IJAEML), 1(2), 66-77. DOI: http://dx.doi.o rg/10.5281/zenodo.1045417.

[22] Aithal, P. S., \& Suresh Kumar,P. M. (2016). Maintaining Teacher Quality in Higher Education Institutions. International Journal of Current Research and Modern Education (IJCRME), 1(1), 701-711. DOI : http://doi.org/10.5281/zenodo.160946. 
[23] Aithal, P. S. \& Suresh Kumar, P. M. (2016). Organizational Behaviour in $21^{\text {st }}$ Century Theory A for Managing People for Performance. IOSR Journal of Business and Management (IOSR-JBM), 18(7), 126-134. DOI: $\quad$ http://doi.org/10.9790/487X180704126134.

[24] Aithal, P. S.\& Suresh Kumar, P. M.(2016). Comparative Analysis of Theory X, Theory $\mathrm{Y}$, Theory Z, and Theory A for Managing People and Performance. International Journal of Scientific Research and Modern Education (IJSRME), 1(1), 803-812. DOI: http://doi.org/10.5281/zenodo.154600. 